\title{
Mediegenre, identifikation og reception
}

\author{
Af Kirsten Frandsen og Hanne Bruun
}

\begin{abstract}
I artiklen satter forfatterne fokus på forholdet mellem personer, der ser på personer $i$ tv. Udgangspunktet er receptionsanalysen og den motivation for tv-sening, der er forbundet med, at tv-seere relaterer sig til og identificerer sig med personer, der optreder på tv (tv-varter, medvirkende osv.). Med afset $i$ en funktionsorienteret definition af genrebegrebet (forskellige genrer etablerer forskellige forventninger, indlevelser osv. hos modtageren) gennemgär forfatterne forskellige teoretiske positioner, der hver isar byder på forskellige forestillinger om forholdet (medie-) tekst og modtageren. Det drejer sig om psykosemiotik, kognitionsteori, parasocial interaktionsteori, mikrosociologisk medieteori og spilteori, som alle har et mere eller mindre eksplicit bud på, hvordan medie og modtagere etablerer relationer som en central del af mediebrugerens motivationer og oplevelser. De forskellige teorier om identifikation danner ifølge forfatterne et kontinuum, spendende fra teorier om den sterke indlevelse til den mere overfladiske indlevelse. Forfatterne advokerer for en mere nuanceret brug af begrebet identifikation, til forskel fra en generel brug af begrebet, som ikke medreflekterer de forskellige teoridannelsers forskellige syn på f.eks. magtforholdet mellem medie og modtager, og som derfor kan have store konsekvenser for analysens resultater.
\end{abstract}

Denne artikel har sin oprindelse i en meget interesseret læsning af Kim Schrøders (2003) artikel i MedieKultur nr. 35, hvor han forsøger at råde bod på receptionsanalysens generelle svaghed i forhold til analysemetode. Kim Schrøder lægger her indirekte op til en metodisk diskussion inden for receptionsanalysen, men vi mener, at hans model åbenbarer, at der også er behov for en teoretisk og begrebsmæssig diskussion, hvis analysen af receptionsdataene skal styrkes og gøres mere gennemsigtig.

På baggrund af mange års erfaring med forskning i mediereception præsenterer Schrøder i artiklen et forslag til en genstandssensitiv og præskriptiv datareduktionsmodel. Der er tale om en dimensionsmodel, hvor fem dimensioner bør indgå i analysen af de kvalitative data. Det drejer sig om motivation, forståelse, konstruktion, holdning og handling. Hver af de fem dimensioner er i modellen forbundet med medieteksten og med hinanden. I analysedimensionen motivation indgår begrebet identifikation som én af de motivationer eller relevansformer, som kan gøre sig gældende i relationen mellem medietekst og modtager. Identifikation fungerer i modellen på linie med begreber såsom 'investering' og 'interesse', 'nysgerrighed' og 'samhørighed' som betegnelse for den "relevans-relation, der kan eksistere mellem, på den ene side, modtagerens tids- og rumligt strukturerede livsverden, og på den anden side medietekstens og brugssituationens univers" (Schrøder, 2003, s. 68). Der er således mulighed for mange forskellige typer af motivationer, der tilsyneladende spænder over et ganske bredt følelsesmæssigt register, og som kan dreje sig om mange aspekter ved medieteksten og brugssituationen.

De mange dimensioner rejser hver især nogle teoretiske problemstillinger, og i det følgende vil vi især se nærmere på identifikationsbegrebet, som både har været meget benyttet i medieteori med et receptionsteoretisk sigte og i konkrete receptionsanalyser. Derfor er det ikke overraskende, at begrebet indgår i et forslag til en analysemetodisk udvikling af genstandssensitive reduktionsmodeller. I alle tilfælde forsøger man hypotetisk at beskrive og dernæst at forklare brugen af et bestemt mediefænomen ved hjælp af begrebet.

Et typisk eksempel på den receptionsteoretiske brug af identifikationsbegrebet kan ses i Tony Wilsons bog Watching Television fra 1993. Wilson lader begrebet beskrive relationen mellem medietekst og modtager i såvel film og tv, og inden for tv bruges begrebet i forhold til en lang række forskellige tvgenrer, fiktion såvel som fakta. Desuden arbejder 
Wilson med et identifikationsbegreb, som spænder over en række forskellige typer af forbindelser mellem medietekst og modtager. Der er tale om seks forskellige bestemmelser, og bredden i begrebsbrugen kan eksemplificeres ved, at Wilson dels mener, at modtagerne kan identificere sig med et landskab, hvor man kunne forestille sig at leve, dels optræder begrebet visse steder i citationstegn (Wilson, 1993, s. 45). Begrebet anvendes med andre ord i en meget bred fænomenologisk optik, hvor identifikation flyder sammen med andre begreber såsom genkendelse, indlevelse, sympati og efterligning, og identifikation er i Wilsons bog et samlende begreb for en mekanisme, der benyttes af modtageren i forsøget på at skabe mening i verden.

Fordi begrebet identifikation tilbyder sig som både en hypotetisk beskrivelse og en forklaring på modtagerens motivation, er faren ved Wilsons brug af begrebet en tendens til en universel og alt for generaliserende brug. Identifikation fremstår derved let som en noget common sense-præget fællesbetegnelse for en form for følelsesmæssig interesse fra modtagerens side, som måske kunne og burde kaldes noget helt andet. Identifikation kan, selvom det faktisk er et uhyre nyttigt begreb, ende med at blive et ikke særlig præcist begreb og en ikke særlig god hypotetisk beskrivelse eller forklaring på modtagerens motivation. I det følgende vil vi følge op på Kim Schrøders forsøg på at udvikle en mere genstandssensitiv databehandling i receptionsanalysen. Vi vil gå i dybden med en lille del af hans model og åbne en mere teoretisk diskussion af begrebsbrugen, idet vi vil sætte mere snævert fokus på, hvordan relationen mellem personer $i$ en to-tekst (verter, medvirkende og spillere) og modtagerne kan forstås. Vi vil ikke forholde os til oplevelse af landskaber, miljøer, situationer etc., da vi mener, at oplevelse af personer er en central motivationsfaktor i megen tv-sening, og at personrelationen derfor er et godt sted at starte, hvis man gerne vil differentiere og nuancere forståelsen af modtagernes reception af tv-tekster.

Som udgangspunkt for diskussionen vil vi argumentere for, at det vil være frugtbart at inddrage $e t$ medie- og genreperspektiv i beskrivelsen af relationen. Inspirationen hertil er hentet i medievidenskabens efterhånden mangeårige forsøg på at integrere teoretiske og metodiske tilgange fra såvel samfundsvidenskab som humaniora. I dansk medieforskning har især kognitiv teori og mikrosociologi spillet en rolle som inspirationskilde til at udbygge et analytisk begrebsapparat hentet primært fra huma- niora. Goffmans mikrosociologiske begreber har eksempelvis været flittigt benyttet i forsøget på at indkredse de kommunikative rammer, normer og appeller i tv's mange og ret forskellige tekster. Medietekstanalysen har derved inddraget den samfundsvidenskabelige dimension i sin begrebsbrug, hvorved den samfundsvidenskabelige inspiration er blevet andet og langt mere end blot en metodisk dimension i receptionsanalysen.

\section{Genrer er mere end tekster}

Relevansen af at inddrage et genreperspektiv i den empiriske receptionsanalyse er påpeget af John Corner i en statusartikel fra 1991, hvor de empiriske modtagerstudier inden for den britiske og amerikanske cultural studies-tradition typologiseres og diskuteres. Corner fremhæver i den forbindelse behovet for, at receptionsanalysen interesserer sig for netop genre ud fra den betragtning, at

Genre is a principal factor in the directing of audience choice and of audience expectations ('shall I watch X?, what might it be like'?) and in the organizing of the subsets of cultural competences and dispositions appropriate for watching, listening to and reading different kinds of things. (Corner, 1991, s. 276)

Corner argumenterer for, at receptionsanalysen til stadighed bør udvide sit empiriske interessefelt og inddrage en række forskellige mediegenrer. Kun derved vil man være $\mathrm{i}$ stand til at få en dybere viden om, hvordan tv-mediet eksempelvis har kulturel betydning. Han advarer desuden mod, at man ud fra nogle få og meget genrespecifikke studier af eksempelvis tv-nyhedsprogrammer eller tv-soap operas drager slutninger om tv-reception generelt. Tv-mediet er netop "both as a formal system and as a social process (...) constituted from often very different communicative forms and activities" (Corner, 1991, s. 276).

Corners argumentation for relevansen af genre som analytisk redskab er helt i overensstemmelse med en funktionalistisk brug af genrebegrebet. I den forståelse af hvad genre er, er interessen rettet mod, hvad genre betyder og gør i kommunikationskredsløbet mellem afsender, tekst og modtager frem for at arbejde på en fastlæggelse af, hvad genre er. Funktion afløser derved definition som det væsentlige. Michael Bruun Andersen (Bruun Andersen, 1994) fremhæver, at genre ud fra den 
betragtning bliver til et samlebegreb for en række forhold i og uden for medieteksten. Genre drejer sig netop om både tekstlige træk, der er stabile og foranderlige, og om forventningshorisonter hos såvel afsendere som modtagere, som ligeledes er stabile og foranderlige. Det funktionsorienterede genrebegreb har således en væsentlig social dimension, der drejer sig om kognitive tekstskemaer såvel som forestillinger om specifikke brugssituationer, der knytter sig til specifikke medietekster hos såvel afsendere som modtagere. Bruun Andersen påpeger, at genrer dermed bliver at betragte som "samfundsmæssige institutioner" (Bruun Andersen, 1994, s. 17). Den sociale dimension i det funktionsorienterede genrebegreb betyder, at det har træk tilfælles med Goffmans frame-begreb, idet frames indeholder de principper, hvormed specifikke sociale situationer defineres, gøres forståelige og tilmed skabes (Goffman, 1974/1986). Frames er således en måde at organisere erfaring på, så den kan benyttes i forhold til nye oplevelser og derved være basis for skabelsen af nye erfaringer. Frames er derfor, ligesom den funktionsorienterede opfattelse af genre, et både statisk og dynamisk fænomen (Bruun Andersen, 1994, s. 6).

Med udgangspunkt i en funktionsorienteret forestilling om, hvad genre gør i en kommunikationsproces, kunne man helt grundlæggende formo$\mathrm{de}$, at forskellige medier og forskellige medietekster nødvendigvis må have forskellige kommunikative funktioner og må tilbyde modtagerne forskellige følelsesmæssige oplevelser. Dette kunne have betydning for den form for relation, der kan tænkes at være mellem mediepersoner i respektive medietekster og modtagerne. Empiriske receptionsstudier har desuden påvist, at der er en sammenhæng mellem genre og receptionen (eksempelvis Höijer, 1991 og 1996, Bruun, 2001 og 2002). Relationen mellem medietekstens personer og modtageren kunne derfor i høj grad være præget af såvel det specifikke medie som den specifikke mediegenre, der kommunikeres ved hjælp af. Eksempelvis er seerens følelsesmæssige relation til en fodboldspiller i en fodboldtransmission ikke nødvendigvis af samme karakter som relationen til en figur i et tvdrama eller en studievært i en nyhedsudsendelse. For at udvikle det synspunkt vil vi i det følgende skitsere en række af de bud, medieanalysen har på en beskrivelsen af relationen mellem mediepersoner og modtagerne, hvor netop det medie- og genreorienterede udgangspunkt har spillet en rolle.

\section{Identifikation - Det psyko- semiotiske identifikations- begreb i medieanalysen}

Inden for medieanalysen har psykoanalysen tidligere været en væsentlig inspirationskilde. Det gælder ikke mindst inden for den Lacan-inspirerede filmsemiologi ${ }^{1}$, hvor mediets særlige teknologiske, udtryksmæssige karakter og selve receptionssituationen i biografen har dannet udgangspunkt for en anvendelse af psykoanalytiske begrebsdannelser i en teoretisk beskrivelse af filmens udsigelsesstruktur og måde at konstruere en modtager på.

Filmmediets brug af lyd og levende billeder - dets særlige filmiske og visuelle karakter - har bl.a. banet vej for en brug af Jacques Lacans psykoanalytiske spejlteori som metafor for forståelse af filmtilskuerens relation til filmteksten. Spejlteorien er hos Lacan udviklet til at beskrive barnets tidlige identitetsdannelsesproces i 6-18 måneders alderen, hvor det endnu ikke er i stand til at skelne mellem sin egen og andres kroppe. Synsdriften bliver et væsentligt redskab for barnet til at udvikle en egen identitet, enten gennem identifikation med sin egen krop i et spejl eller ved i metaforisk forstand at spejle sig i andres kroppe. En grundmotivation for denne proces er barnets ønske om at overkomme nogle af de mangler, som det oplever at have i forhold til omgivelserne. Set i forhold til mediereception er grundtanken, at spejloplevelsen udgør en form for ur-identifikation, som kommer til at danne skema for, hvordan alle senere identifikationer vil foregå.

Set i forhold til f.eks. trykte medier og lydmedier har filmmediet i sanselig henseende et mere sammensat udtryk, som modtageren oplever i nu'et i biografen. Denne oplevelsesmæssige umiddelbarhed, hvor et komplekst sæt af tegn opleves situativt uden mulighed for, at modtageren kan stoppe op eller gentage oplevelsen ${ }^{2}$, har sammen med filmens særlige tekstlige organisering af indholdet ledt til, at filmlærredet er blevet opfattet som spejl nr. to. I forlængelse heraf er billedmedierne generelt blevet opfattet på linje med litteraturen som særligt følelsesmobiliserende. For biograffilmens vedkommende understøttes dette yderligere af receptionssituationen i biografens mørke, hvor den enkeltes opmærksomhed forudsættes at være $100 \%$ rettet mod det oplyste lærred. Disse forhold har tilsammen skabt et særligt receptionsklima, hvor ubevidste lag og regressive oplevelsesformer hos modtageren i særlig grad kan 
aktiveres. Oplevelsesformer, der har store ligheder med de oplevelsesformer, som modtageren i sin tidlige barndom har gennemlevet i spejlfasen, og oplevelsesformer, hvor ubevidste lag i modtagerens bevidsthed har stor betydning for det, som er blevet kaldt den "virkelige oplevelse" af medieteksten (Sørensen, 1994, s. 85). Tanken er, at modtageren etablerer en overføringsrelation til det afbildede i $\mathrm{og}$ med at vedkommende bevidst og frivilligt giver afkald på bevidstheden om, at det afbildede er en konstruktion og en illusion. Motivationen herfor er en slags ønskeopfyldelse, hvor modtageren gennem oplevelse af medieteksten og dens personer făr bearbejdet nogle af de følelsesmæssige savn og mangler, som socialisationsprocessen har grundlagt i personen. Overføringsrelationen kan både tage form af en identifikation eller en projektion.

Modtagerens relation til medietekstens personer forudsætter en generel primær identifikation med kameraets blik, hvorved modtageren sætter sig selv i centrum for billedet og bliver alt-perciperende. Først i logisk forlængelse af denne oplevelsesindstilling kan relationen med personer i teksten - kaldet den sekundære identifikation - finde sted. Denne identifikation ses som en parallel til barnets tidlige identifikation med anden-kroppen i spejlet. Modtageren, som i udgangspunktet oplever sig selv som ufuldendt med en række mangler af f.eks. psykosocial, seksuel eller eksistentiel art, søger i oplevelsen af medieteksten at kompensere herfor ved via selvforglemmende indlevelse $\mathrm{i}$ bestemte personer i teksten, ubevidst at suge næring til sig til brug i sin egen identitetsdannelse.

Den store styrke ved den filmsemiotiske tilgang til at forstå relationen mellem medietekster og personer er den ekspliciterede, mediespecifikke forståelse, der ligger i påpegningen af det audiovisuelt specifikke. Som en række medieforskere har fremhævet (bl.a. Højbjerg, 1989 og Harms Larsen, 1990) opstår der dog et problem, når de psykoanalytisk funderede forståelser, der er udviklet i forhold til fiktionsfilm i biografen, overføres på et andet billedmedie. Tv-mediet er i sit audiovisuelle udtryk anderledes end biograffilmen, har en helt anden receptionssituation, og er genremæssigt langt mere mangfoldigt sammensat.

Trods denne kritik er en anden styrke ved den filmsemiotiske tilgang det implicitte genrebegreb, idet der er en bevidsthed om, at den tekstlige organisering spiller en væsentlig rolle for modtagerens oplevelse. Eftersom synspunkterne udelukkende er baseret på iagttagelser knyttet til spillefilm, og eftersom der drages paralleller til andre affektive kunstarter som skønlitteratur, er det overvejende en fiktionsteori. Identifikation forstået som en jeg-fortabelse og midlertidig afgivelse af kontrol er måske at betragte som et tværmedialt træk ved fiktionsgenren, hvor modtageren identificerer sig med en handlende persons projekt. De audiovisuelle medier kunne dog tilmed tænkes at have et fortrin i etableringen af denne relation.

For os at se kan identifikationsbegrebet i denne veldefinerede aftapning sandsynligvis være velegnet til at sætte begreb på relationen mellem modtager og fiktive teksters personer. Men denne brug af begrebet fremstilles dog ofte som universel for audiovisuelle medier som helhed, og derved bliver den reelt brugt på andre medier og andre genrer. Et andet problem kan være den modtageropfattelse, som ligger implicit i det psykoanalytiske perspektiv, idet modtageren grundliggende opfattes som et individ med en række modale mangler, betinget af socialisationsprocessen, og som mediebrugen skal medvirke til at kompensere for. Sat på spidsen er det en i psykologisk henseende skadet og syg modtager, som i sin mediereception er styret af ubevidste processer, og som henfalder til et infantilt oplevelsesniveau, vi har at gøre med her.

I dansk sammenhæng har Peter Harms Larsen i sin bog om tv-faktion (Harms Larsen, 1990) forsøgt at arbejde videre med den psykosemiotiske tilgang og indirekte råde bod på nogle af problemerne ved at overføre det til tv-mediet og ikke mindst til faktagenrerne. Han viderefører den psykoanalytiske Lacan-inspiration, men forsøger at differentiere identifikationsbegrebet for at gøre det anvendeligt i forhold til netop faktuelle genrer og forskellige blandinger af faktuelle og fiktive fremstillingsformer. Hans ærinde er dog ikke at bidrage til receptionsteorien, men at opbygge en teori til produktionel brug. Dette implicerer bl.a. en forståelse af sammenhængen mellem brug af forskellige udtryksformer og seernes oplevelse. Selvom han i udgangspunktet differentierer identifikationsbegrebet som havende to grundbetydninger: at genkende ud fra et forhåndskendskab eller at gøre sig til ét med et andet menneskes/dyrs liv og interesser, fastholder han, at begrebet må rumme begge dele (Harms Larsen, 1990, s. 161-162). Ved at fastholde dobbeltheden vedbliver begrebet at være et noget diffust begreb.

Forsøget på en genremæssig differentiering får dermed det problem, at der for det første tages 
udgangspunkt i dette noget diffuse begreb, og for det andet fastholdes den psykoanalytiske tilgangsvinkel som det eneste teoretiske udgangspunkt. Som nævnt er en af styrkerne ved Harms Larsens bidrag, at han faktisk forsøger at indføre et grovkornet genreperspektiv, idet han har et behov for at kunne skelne mellem fakta og fiktionsgenrer på netop tv. I den forbindelse føjer han til den primære og sekundære identifikationsform en tertiær form, som er en genkendelse af autoriteter og barndommens billede af autoriteter (Harms Larsen, 1990, s. 162). De tre identifikationsformer har dog det tilfælles, at modtageren i alle tilfælde genkender eller genoplever ved en slags spejling af indre skabeloner og matricer i det audiovisuelle udtryk, og at disse processer er følelsesladede. Selvom Harms Larsen har et mere eksplicit genreperspektiv og rummer en række gode tiltag, er fraværet af et mere eksplicit og veludviklet medieperspektiv iøjnefaldende. Han er opmærksom på forskellen på biograffilm og tv, men en diskussion af f.eks. spejlteoriens anvendelighed i forhold til tv-mediet og faktuelle genrer mangler, for at man kan forstå seernes relation til f.eks. studieværter, som kun i meget begrænset omfang udtrykker deres personlige individualitet, eller til oplevelse af personer i faktuelle genrer i det hele taget, som ikke bygger på fiktionskontrakten om, at der er tale om en illusion.

Dette opgør med spejlteorien tager John Ellis indirekte i bogen Visible Fictions (1982), hvor han i en sammenligning mellem biograffilmen og tv især hæfter sig ved de store forskelle i receptionssituationen og forskellen mellem det store biograflærred og den lille tv-skærm. Tv's størrelse, placering og mere rutinemæssige brug i hjemmet har ifølge Ellis betydning for seerens koncentration og engagement. Det betyder bl.a., at tv's tekster er organiseret efter andre principper end biograffilmen, da tv konstant konkurrerer om seerens opmærksomhed med en lang række andre aktiviteter og instanser i hjemmet (Ellis, 1982, s. 163). Dermed er relationen mellem tekst og modtager også af en anden karakter, idet seeren er langt mindre koncentreret og dermed anderledes disponeret for at indleve sig i tekstens univers og personer. Som Ellis selv påpeger, udgør dele af fiktionsteksterne dog en undtagelse:

Broadcast TV assumes that its viewer will need to be drawn back to each susccessive segment, except in the most prestigious drama based on filmic og theatric modes of attention. (Ellis, 1982,s. 163)

Til at begrebsliggøre forskellen i koncentration bruger Ellis to begreber for netop blikket på henholdsvis biograffilmen og tv-teksten, som implicit rummer et opgør med spejlteorien:

It is not the TV viewer's gaze that is engaged, but his or her glance, a look without power. It is not the viewer's look that is at stake in the process, but the look of TV itself on to at world beyond. There is no voyeuristic separation for the TV viewer as there is for the cinema viewer (Ellis, 1982, s. 163 - Frandsens og Bruuns fremhævelse)

Som det gerne skulle fremgå af citatet, er en del af grunden til opgøret med filmsemiotikkens fokusering på synsdriften som central motivation i modtageprocessen, at tv i indhold og genrer har en langt stærkere forankring til den omgivende virkelighed end biograffilmen.

Ellis har således en fornemmelse for genrernes betydning, men eftersom hans primære interesse er at give en karakteristik af tv-teksten som helhed, kommer han ikke videre ind på implikationerne for seerens relation til personer i forskellige genrer. En stor del af hans eksempler er dog hentet fra fiktionen og rummer derfor gode ansatser til at beskrive relationen mellem tv-seeren og personer i f.eks. en tv-specifik fiktionsgenre som soapen. Her gør han bl.a. opmærksom på, at skuespillerne i en soap for seeren ofte bliver identisk med de fiktive figurer, som de spiller. Den stærkere virkelighedsforankring lægger således op til at forstå relationen som noget andet end en momentan og stærkt følelsesladet 'gåen op' i en anden person.

\section{Simulation - kognitions- teoretisk udgangspunkt i medieanalysen}

Et andet bud på en beskrivelse af relationen mellem mediepersoner og modtagerne er at beskrive den som et simulationsforhold frem for et identifikationsforhold. Denne tilgangsvinkel kan iagttages hos Torben Kragh Grodal. Udgangspunktet for Grodals receptionsteori om audiovisuel fiktion (film) er kognitionsteoretisk, og i første omgang repræsenterer hans teori et frontalt opgør med og angreb på den psykosemiotiske filmteori, hvor Metz' Lacan-inspirerede begrebsapparat er udgangspunktet. Det betyder, at der argumenteres imod at betragte filmsening som en primært individpsykologisk praksis, hvor præødipale tilstande og konflikter aktiveres. Hos Grodal (1997), og andre kognitions- 
teoretiske filmteoretikere, er der et ønske om at indkredse de grundlæggende mekanismer, der kan beskrive filmtilskuerens mentale arbejde med at skabe betydning ud af det oplevede. Filmsening generelt $\mathrm{og}$ forholdet mellem mediepersonerne og modtagerne fremstilles hos Grodal som en aktivitet, der hviler på artsbestemte biologiske og evolutionsbetingede forudsætninger for at skabe sociale bånd. Disse forudsætninger indgår i receptionsprocessen i et samspil med filmens udtryksmæssige og indholdsmæssige udspil. Det emotionelle forhold til mediepersonerne er dermed både en konsekvens af en grundlæggende måde, vi som mennesker forstår vores omverden på, hvor følelserne og de følelsesmæssige relationer spiller en central rolle i denne tilegnelsesproces, og en konsekvens af filmens fremstilling af sine personer.

Selvom der i princippet ikke er nogen forskel på det mentale arbejde, som modtageren præsterer $\mathrm{i}$ forhold til virkeligheden og i forhold til filmen, så er det samtidig en grundantagelse hos Grodal, at modtageren ingen problemer har med at skelne filmfiktionen fra virkeligheden. Modtageren "performs hypothetical 'as if' simulations of situations" (Grodal, 1997, s. 94), og dette kan sammenlignes med menneskets evne til at forestille sig begivenheder og de følelsesmæssige konsekvenser af disse i fantasien. Det er en artsbestemt og intelligensstyret følelsesaktiverende leg, som fiktionen giver anledning til, der beskrives således

When we agree to watch visual fiction, we accept a set of rules of experience and establish a viewerpersonae, a mental model of the viewer as spectator of fiction, and this viewermodel, this personae, feels suspense, happiness, fear, and sadness as if witnessing similar phenomena in the non-fictive world (Grodal, 1997, s. 103).

Situationerne forstås, følelserne føles, og der fældes måske ægte tårer, men handlingerne udebliver. Simulationsbegrebet erstatter således det i filmteorien så belastede identifikationsbegreb, og i Grodals Filmoplevelse - en indforing $i$ audiovisuel teori og analyse fra 2003 udfoldes simulationsbegrebet og den tilgangsvinkel til relationen mellem mediepersoner og modtageren yderligere. Filmtilskuerens simulering kan i et vis omfang styres via den centrering om bestemte karakterer, som filmen lægger op til. Dermed kan placering af tilskuerens følelser påvirkes, idet dette kan være et produkt af en længerevarende karaktercentrering og et produkt af, hvem der i øvrigt optræder i filmen. Egenskaber, som tilskueren værdsætter, vil derfor spille en væsentlig rolle, og det samme vil den kontekst, som filmen skaber for sine personer (Grodal, 2003, s. 148-55).

I begge Grodals bidrag er genreaspektet desuden vigtigt $\mathrm{i}$ filmtilskuerens simulering, idet bestemte prototypiske filmgenrer lægger op til særlige følelsesmæssige reaktioner. Udgangspunktet er forestillingen om teliske og parateliske strukturer i prototyperne, hvilket har konsekvenser for filmtilskuerens måde følelsesmæssigt at relatere sig til filmens personer, deres projekter og hele filmens handlingsunivers på. Et eksempel på en telisk domineret genre er actionfilm, hvor der lægges op til, at tilskueren simulerer den handlende og målrettede helts følelser. Melodramaet er derimod domineret af en paratelisk struktur, hvor der eksempelvis lægges op til, at tilskueren simulerer den skæbneramte hovedpersons følelser.

Simulationsbegrebet samt de genremæssige forankringer, det giver, er således et bud på en beskrivelse af relationen mellem mediepersoner og modtagere, hvor der er en teoretisk forankring og en differentiering i begrebsbrugen. Men teorien er samtidig knyttet til spillefilm. Der er således en genrerelatering i begrebsbrugen, og spørgsmålet er selvfølgelig, om de teoretiske bestemmelser kan anvendes på fiktion i tv. Har bestemmelserne med andre ord en generaliseringsværdi til al audiovisuel fiktion, eller er de kun møntet på og eventuelt virksomme i forhold til spillefilm. I Grodal (2003) inddrages forskellen på film og tv-fiktion kort, dog ikke i forbindelse med forholdet til mediepersonerne, men i et kapitel om film og fortællinger (Grodal, 2003, s. 173-213). I et kort afsnit (s.192-94) nævnes det, at den serielle struktur i det meste tv-fiktion giver nogle fortællemæssige begrænsninger og muligheder, som er anderledes. Det samme gør den anderledes brugssituation, som tv indgår $i$, idet tv-fiktionen "forudsætter et langt mere distraheret publikum end film" (Grodal, 2003, s. 193). Dog bringes simulationsbegrebet og de genremæssige bestemmelser ikke i anvendelse i forhold til tv-fiktionen. En diskussion, som derfor kan rejses på baggrund af den kognitionsteoretiske tilgangsvinkel, er, hvilken rolle selve mediekonteksten og brugskonteksten kunne tænkes at spille. Har det eventuelt en betydning for de følelsesmæssige relationer til mediepersonerne, at tv-mediet indeholder meget mere end alene fiktionstilbud til seerne? Et eksempel på, at det muligvis spiller en rolle både for seernes oplevelse og for den måde, der 
produceres tv-fiktion på, kan være situationskomedien. I denne tv-fiktionsgenre er det almindeligt, at serierne bærer hovedrolleskuespillerens virkelige navn, eksempelvis Seinfeld, Rosanne og Ellen, og at grænsen mellem rollen og skuespillerens person er noget porøs f.eks. Casper i Langt fra Las Vegas spillet af Casper Christensen. Man kunne her forestille sig, at det har betydning, at tv-mediet desuden spiller en noget anden rolle i modtagerens daglige medieforbrug, end biografen gør. Der er, som Grodal nævner, tale om meget forskellige brugssituationer, som måske også influerer på oplevelsen af den store mængde filmsening, der faktisk foregår via tv-mediet eller som video. Disse aspekter spiller dog ikke nogen stor rolle i Grodals teoretiske bestemmelser, idet vi med meget få undtagelser bevæger os fra filmen direkte til tilskuerens mentale modtageapparat uden den slags kontekstuelle 'mellemregninger'. De sociale erfaringers betydning for de kognitive processer samt en større interesse for netop den sociale dimensions betydning i det hele taget kan til gengæld findes i den sociokognitive receptionsteori ( f.eks. hos Höijer \& Werner, 1998). Her er tekstbegrebet og det tekstanalytiske begrebsapparat i forhold til medieteksterne derimod ikke særlig udviklet.

\section{Parasocialitet, roller og spil - de sociologiske tilgange}

Tre andre bud på en beskrivelse af relationen mellem mediepersonerne og modtagerne, som i høj grad henter argumenterne i den sociale dimension frem for den biologiske, kan findes i henholdsvis parasocial interaktionsteori, mikrosociologisk medieteori og spilteori.

Horton \& Wohls berømte, og fortsat relevante, teori fra 1956 om tv-sening anskuet som en parasocial aktivitet, repræsenterer både en socialpsykologisk tilgangsvinkel samt en mediespecifik tilgangsvinkel, som tilmed rummer en række genremæssige overvejelser. Horton \& Wohls udgangspunkt er, at forholdet til mediepersonerne kan beskrives med baggrund i de forhold, dimensioner og kendetegn, der er ved vores interpersonelle interaktion (verbalt og non-verbalt). Tv-mediet giver mulighed for en særlig form for interpersonel interaktion, som er analog til almindelig interaktion i primærgrupper, men adskiller sig med hensyn til grad (Horton \& Wohl, 1956/97, s. 27). De kalder denne form for interaktion for parasocial, og den opstår i forholdet mellem tv's værter - personaen - og seerne. Den af- gørende forskel fra almindelig interaktion er fraværet af reciprocitet. Det er derefter artiklens formål at indkredse, hvad der er forudsætningen for, at det parasociale kan opstå, og hvad der kendetegner tv's forsøg på at skabe parasociale relationer. Dernæst udkastes en teori om, hvad de oplevelsesmæssige værdier i det parasociale kan være for tv-seerne.

Forudsætningen for, at det parasociale kan opstå, er, at kontakten mellem personaen og seerne er regelmæssig og stabil, og at personaens opførsel er relativ forudsigelig. TV's sendefrekvens og de konkrete programmers levetid kan levere dette grundlag, og de to træk kan dernæst støttes af iscenesættelsen af personaen. Iscenesættelsen er kendetegnet ved at benægte fraværet af reciprocitet og ved at benægte den anonyme og upersonlige form for kommunikation, som tv reelt er. Der insisteres på at give seerne en oplevelse af kontakt til personaen. Det kan ske ved, at seerne tiltales via kamerakontakten, at den uformelle interaktions gestik, konversationsstil og eventuelle miljø bruges i programmerne. Desuden kan det ske ved, at værten inddrager såvel produktionshold som publikum i studiet i en kammeratlig og personlig tiltale og inddrager selve mediet og dets teknik i sin optræden. Alt dette er med den hensigt at sløre afstanden mellem personaen og seerne, og sløre programmet som en formel optræden og seerne som en anonym masse.

De oplevelsesmæssige værdier for seerne i den parasociale rolle kan ifølge forfatterne være muligheder for rolleafsøgning, rolleafprøvning og rollegenopfriskning for individet pr. stedfortræder. Desuden kan den parasociale rolle give mulighed for at gennemspille idealiserede roller, som hverdagslivet sjældent eller slet ikke giver mulighed for. Opførselsmønstre kan samtidig analyseres og øves, alt sammen pr. stedfortræder. Endelig fremhæver Horton \& Wohl, at indslag af samtaler med seerne i programmet, f.eks. i form af telefonopringninger til personer i programmet, kan give fornemmelsen af at være med i "denne helende ceremoni" for seerne (Horton \& Wohl, 1956/97, s. 33). De oplevelsesmæssige værdier i det parasociale minder en del om, hvad Grodals kognitionsteoretiske filmteori fremhæver kendetegner relationen mellem mediepersoner og modtageren. Forskellen hviler dog på fremstillingernes realitetsstatus, idet simulationen sker i forhold til erkendte fiktive personer $\mathrm{og}$ universer og det parasociale sker i forhold til erkendt mangel på "rigtig gensidighed" i forholdet til personaen (Horton \& Wohl, 1956/97, s. 27). 
På baggrund af beskrivelsen af det parasociale og de formodede oplevelsesmæssige værdier for seerne i dette bliver spørgsmålet teoriens generaliseringsværdi. Horton \& Wohl er lidt uklare, hvad dette angår. Udgangspunktet er, at tv-mediet som sådan er det grundlæggende for relationen, men radio nævnes også. Hvorvidt relationen kan bevæge sig på tværs af fakta og fiktion er også uklart. F.eks. lægger forfatterne ud med at skrive bredt om de mange forskellige typer af mediepersoner, der kan opleves i radio og tv (Horton \& Wohl, 1956/97, s. 28). Men dernæst snævrer de perspektivet ind til alene at dreje sig om mediepersonaer, som er defineret ved at være "en særlig kategori af 'personligheder', hvis eksistens er en funktion af medierne selv" (s. 28). Endelig har de nogle præciseringer, der tyder på, at det netop alene er i forhold til faktagenrer, at det parasociale kan opstå, idet publikum placeres i en potentiel svarerrolle $\mathrm{i}$ forhold til personaen

I denne rolle bibeholder tilskueren kontrollen over indholdet $\mathrm{i}$ sin deltagelse, snarere end at overgive kontrol gennem identifikation med andre, som han gør når han er optaget af at se et drama eller en film. (Horton \& Wohl, 1956/97, 30).

Det er endvidere lidt uklart, om det parasociale alene gælder mediets 'egne' personer, dvs. værter og ankerpersoner af enhver art, eller om det også gælder i forhold til deltagerne i programmerne.

Trods disse uklarheder er den parasociale interaktionsteori fortsat et bidrag til en differentieret begrebsbrug og en præcision, som er uhyre nyttig i analysen af værtsbårede faktaprogrammer på tv. Samtidig er der rig mulighed for at udbygge teorien ved at specificere det parasociale yderligere $\mathrm{i}$ forhold til forskellige former for værtsbåret fakta-tv. Eksempelvis kunne man forestille sig, at det parasociale former sig ganske forskelligt afhængig af, om vi har med et talkshow, et nyhedsprogram eller et quizprogram at gøre. Teorien kan dermed fortsat være et vældig nyttigt receptionsteoretisk udgangspunkt for eventuelle empiriske receptionsanalyser.

\section{Mikrosociologisk medieteori}

Et bidrag til at udbygge et genreorienteret omdrejningspunkt for en beskrivelse af relationen mellem personer i tv-mediet og seerne kan eksempelvis findes i interessen for tekstanalyse med udgangspunkt i mikrosociologiskinspireret medieteori. Joshua Me- yrowitz' No Sence of Place fra 1985 er her en væsentlig inspirationskilde til en form for medieanalyse, der tager udgangspunkt i tv-mediets grundlæggende karakteristika som massemedie og i mikrosociologiske begreber til beskrivelse af face-to-face interaktion. Meyrowitz' videreudvikling af Erving Goffmans scenemetafor og tilhørende rolleteori er her et væsentlig omdrejningspunkt $i$ analyserne af årsagen til bestemte tv-genrers succes blandt seerne. I en række tv-genrer bearbejdes forholdet mellem den offentlige og private sfære, og mediets præsentative og verbale karakter i kombination med brugssituationen i hjemmet betyder, at der i tv opstår en særlig sfære. Meyrowitz kalder denne sfære for en "middle region", og den er karakteriseret ved at være privat og offentlig på en og samme gang. Desuden inddrages Goffmans face-begreb i analysen af, hvordan mediepersonerne behandles og opfører sig, og hvordan relationen til seerne kan tænkes at forme sig. Denne tilgangsvinkel søger således at forene de samfundsvidenskabelige og de humanistiske dimensioner i medievidenskaben i en tekstanalytisk praksis. Ofte er denne praksis knyttet til udforskningen af specifikke mediegenrer især inden for de tv's faktuelle genrer.

Et eksempel på kombinationen af mikrosociologisk medieteori og mediegenreanalyse kan findes i Stig Hjarvards artikel "Seernes reality" i MedieKultur nr. 34 fra 2002, der er et temanummer om reality-tv. Seernes relation til de medvirkende i reality-programmerne beskrives som tæt forbundet med faktaoverenskomsten, idet genren er kendetegnet ved, at deltagerne i reality-programmerne har reel eksistens, og deres handlinger har derfor også konsekvenser uden for programmet. Desuden er målet med virkelighedsskildringen ikke sandhed, som i de journalistisk prægede fakta-tv-genrer, men at seerne gives en oplevelse af autenticitet. Genren tilbyder dermed

(...) mulighed for at iagttage den interpersonelle interaktions mikrounivers, hvor almindelige mennesker som seeren selv handler i situationer, der har reelle konsekvenser for deltagerne. Genren kan med andre ord bruges af seeren som medieret eksperimentel erfaringstilegnelse om den mikrosociale interaktions kendetegn, herunder forøge kendskabet til repertoiret og normerne for adfærd i forskellige konflikt- og konsekvensfyldte situationer. (Hjarvard, 2002, s. 94)

Tv-programmernes medvirkende bidrager i den forstand med et udspil til seernes egen identitets- 
afsøgning og værdimæssige orientering i forhold til en omverden, hvor medierne i sig selv udgør en scene med specifikke sociale normer. Der er således et tilbud om en bearbejdning af såvel situationsbestemte sociale normer, som seerne har erfaringer med, og en bearbejdning af de normer for social adfærd, der knytter sig specifikt til den mediemæssige iscenesættelses "middle region".

Det analytiske arbejde, der forestår, er derfor at påpege, hvilke specifikke sociale normer, der sættes til diskussion og bearbejdning i konkrete genremæssige og konceptuelle rammer. Med andre ord: hvordan arter mødet mellem sociale normer, mediegenre og programkoncept sig, og hvordan former det relationen mellem seerne og mediets personer? Karakteren af og forskellen mellem det normative udspil i eksempelvis Robinson Ekspeditionen (TV3), Sporlos (DR1) og Station 2 (TV 2) vil derfor være central for den form for motivation, seerne kan have for at se det specifikke program.

\section{Spilteori}

Udgangspunktet i mikrosociologisk medieteori betyder, at tv-teksten betragtes som en social situation, og det åbner for en sammentænkning med typer af sociologisk teoridannelse, hvor der er sat fokus på specifikke sociale situationer. Det kan være teorier udviklet til fænomener uden for medierne, der bliver til en del af tv's indhold. Teorierne kan bidrage til at belyse, hvorledes de enkelte genrer på grund af indholdet kan sætte specifikke rammer for relationen mellem tv-tekst og modtagerne. Et eksempel herpå er sociologen George Simmels begreb om selskabelighed, som har været anvendt i forhold til talkshow-genren (Bruun, 1999). Endvidere har sportssociologen Susan Birrells sammentænkning af Goffmans og Dürkheims ritualbegreber i en bestemmelse af sportsbegivenheden været brugt til at forstå mediernes rolle ved dækning af sportsbegivenheder (Frandsen, 1996).

Det rituelle perspektiv betyder noget for oplevelsen af de agerende personer i en sportstransmission, idet disse personer ifølge Dürkheim overtager de hellige symbolers funktion som bindeled mellem det oplevende individ og det moralske normsæt, som ritualet formidler. De spiller en rolle af samfundsmæssig betydning.

Sportsbegivenheden er en iscenesat situation, som med Goffmans termer kan bestemmes som en outreret actionsituation, der byder på en særlig høj grad af risiko for de deltagende personer. Netop derfor rummer sportsbegivenheden særlige muligheder for at demonstrere karakter. Sportspersonernes opførsel på sportsarenaen er således indirekte styret af en række idealroller, idet personerne hver især forsøger at demonstrere moralske egenskaber ved idealrollen, som har høj samfundsmæssig værdi. Netop den Goffman-inspirerede bestemmelse af sportsbegivenheden som en outreret situation, der er iscenesat med henblik på offentlig beskuelse, betyder, at dette perspektiv også kan have relevans i forhold til andre tv-genrer end sportstransmissionen. Det gælder ikke mindst i forhold til nogle af de ovennævnte nye reality-shows, hvor forskellige elementer fra både game- og dokumentargenrerne netop er blandet sammen. Men konkurrence- og spilelementets betydning for seerens relation til de deltagende personer overses ofte.

Set i et spilperspektiv ${ }^{3}$ har deltagerne, hvad enten det er en fodboldspiller eller en quizdeltager, nemlig i lighed med skuespilleren i fiktionen påtaget sig en rolle. Men her har rollen en anden realitetsstatus end i fiktionen. Personerne spiller nemlig ikke en opdigtet figur, da spillet jo foregår i virkeligheden, og personerne jo fortsat er sig selv. Ikke desto mindre spiller de en rolle, som er defineret gennem spillets konstitutive regelsæt. Regelsættet definerer kun personens funktion og muligheder i forhold til spillet og sætter således en række begrænsninger for, hvilke sider af spillerens personlighed som kan komme til udtryk. Personen/spilleren må med andre ord underlægge sig spillets regler, for at spillet kan køre og nå sit mål, der ofte er at få udpeget en vinder. På fodboldbanen betyder det f.eks., at spillerne må underkaste sig fodboldspillets regler og underordne sig dommerens afgørelser, ellers går spillet i opløsning $\mathrm{og}$ når ikke sit mål. Inden for spillets rammer er det kun en begrænset del af fodboldspillerens personlighed, der kan komme til udtryk. Vedkommende bliver til en spillerpersonlighed, en stereotyp, som kun er interessant som person i kraft af den måde, hvorpå han/hun lader sin personlighed komme til udtryk gennem spillet. Alt andet ved personen er irrelevant og opleves som uvedkommende ${ }^{4}$. Set i dette perspektiv er personerne i spillet for seeren ikke genstande for en stærk følelsesmæssig selvforglemmende identifikation, hvor man 'går op' i en anden person. Personernes stereotype karakter betyder, at de mere fungerer som en slags mentale indgange til at opleve selve spillet og dets iboende spænding end som egentlige individer. Det er med andre ord ikke 
personerne, men spillet, som står i centrum for og er styrende for oplevelsen. I det øjeblik, hvor der er flere deltagere i spillet, eventuelt flere forskellige roller og forskellige faktiske personligheder, der fylder dem ud, har seeren en mulighed for at vælge den mentale indgang, som er i størst overensstemmelse med seerens egen mentalitet. Eller seeren kan vælge den person, som bedst udtrykker vedkommendes personlighedsideal.

\section{Opsamling}

Som vi ser det, byder de her skitserede begrebsdannelser på et interessant mulighedsfelt for at analysere og forstå forskellige typer af indlevelse i personer, der optræder i tv-tekster. Selvom feltet genremæssigt overhovedet ikke er udtømmende, idet f.eks. nyhedsgenren ikke er repræsenteret, mener vi, at der tegner sig en mulighed for se det som et kontinuum inden for hvilket, man kan undersøge seerens indlevelse. I den ene ende af dette kontinuum har seeren en meget stærk indlevelse, som er karakteriseret ved, at virkelighedsreferencen bevidst sættes ud af kraft. Seeren giver desuden afkald på kontrol for at opleve en stærk følelsesmæssig 'sætten sig selv' i en andens sted for at få tilgodeset og bearbejdet en række dybtliggende psykologiske behov. Her er begrebet identifikation sandsynligvis helt på sin plads. I den anden ende af et sådan kontinuum er der tale om en følelsesmæssig mere begrænset og dermed overfladisk indlevelse, idet man som seer knytter an til en psykologisk set smalspektret rolle i en både veldefineret og stærkt begrænset social situation. Her gives seeren hverken stof eller plads til at investere hele sin sammensatte psykiske individualitet på én gang. Indlevelsen kan her tænkes at have karakter af at være en bevidst og eksperimenterende rolleafprøvning, gerne på flere supplerende roller samtidig.

Midt imellem disse to poler befinder den kognitive tilgang sig, idet indlevelsen i denne optik er udtryk for en almen biologisk betinget interesse for artsfæller. Motivationen for indlevelsen er dermed et mere alment ønske om via simulation at få oplevelser. Oplevelser som man måske ellers ikke selv har mulighed for at fă, og som man kan bruge til at

\section{Litteratur}

Birrel, S. (1980). Sport som ritual. Centring, 3, årgang 1

Bruun Andersen, M. (1994). TV og Genre. In Peter Dahlgren (red.), Den Mångtydiga Rutan. Stockholm: Skriftserien JMK. vedligeholde og forbedre sine sociale færdigheder og dermed på langt sigt sikre sin overlevelse.

Ved at inddrage medie- og genreperspektivet i analysen af relationen mellem seere og personer i tv-tekster kunne en større forståelse af mediernes kulturelle betydning forhåbentlig nås. Men samtidig kan en helt grundlæggende diskussion rejses: De forskellige teoretiske bud på en beskrivelse af relationen mellem seere og tv's personer bygger, som det er fremgået, på nogle subjektopfattelser, som ikke umiddelbart er forenelige. At abonnere på én af disse har således ganske omfattende konsekvenser, idet der med den grundlæggende subjektopfattelse formodentlig også følger en publikumsopfattelse og ikke mindst en medieopfattelse. Det betyder, at $\mathrm{i}$ de forskellige teoretiske bud er magtforholdet mellem medieteksten og modtageren i betydningsog tilegnelsesprocessen tilsyneladende opfattet ret forskelligt afhængig af, om man f.eks. tager afsæt i en Lacan-inspireret filmsemiologi eller en socio-kognitiv mediereceptionsteori. Den form for påvirkning af modtagerne, som medierne er i stand til at udøve, er dermed ret forskellig, idet vi eksempelvis bevæger os fra stærke individpykologiske påvirkninger af den enkelte modtagers ubevidste til påvirkninger af det primært socialpsykologiske og den praktiske bevidstheds niveau. På baggrund at en sådan diskussion kunne man ende med at bidrage til en teoretisk (re)fokusering af en af medievidenskabens mest indsigtsgivende discipliner. Desuden vil resultaterne af de konkrete receptionsundersøgelser kunne fortsætte med at informere den offentlige debat om mediebrug på et mere præcist grundlag. Ved netop at udskifte eller supplere begrebet identifikation med andre termer kan debatten om f.eks. mediernes positive eller negative påvirkning af f.eks. børn og andre svage sjæle gives et løft. Ved en fortsat unuanceret brug af begrebet identifikation, vil medieforskningen - måske utilsigtet - understøtte bestemte forestillinger om mediernes skadelige virkninger, idet man med begrebet aktiverer bestemte populære forestillinger om især billedmediernes evne til at forføre og manipulere et forsvars- og viljesløst publikum.

Bruun, H. (2002). Global tv-genre og komplekse nærhedoplevelser. Dansk Sociologi, 2, 13. årg.

Bruun, H. (2001). Ricki Lake i Danmark. Receptionen af et amerikansk og et dansk daytime talksho. (Arbejdspapir nr. 6). Global Media Cultures. 
Bruun, H. (1999). Talkshowet. Portret af en tv-genre. København: Borgens Forlag

Callois, R. (2001). Man, Play and Games. Chicago: University of Illinois Press.

Corner, J. (1991). Meaning, Genre and Context: The Problematics of 'Public Knowledge' in the New Audience Studies. In J. Curran \& M. Gurevitch (Eds.), Mass Media ES Society. London: Edward Arnold.

Ellis, J. (1982). Visible Fictions. London: Routledge.

Frandsen, K. (1996). Dansk Sportsjournalistik. Fra sport til publikum. Danmarks Journalisthøjskole, Århus. Licentiatafhandling, DJH-Rapport.

Gantz, W. \& Wenner, L.A. (1998). Watching Sports on Television: Audience, Experience, Gender, Fanship, and Marriage. In L.A. Wenner, Media Sports. Boston: Routledge.

Goffman, E. (1974/1986). Frame Analysis. An Essay on the Organization of Experience. Boston: Northeastern University Press.

Grodal, T.K. (2003). Filmoplevelse - en indforing $i$ audiovisuel teori og analyse. København: Samfundslitteratur.

Grodal, T.K. (1997). Moving Pictures. Oxford: Oxford University Press.

Hansen, N.G. \& Stjernfeldt, F. (1988). Fodbold - spil, struktur og udvikling. In Litteratur \&' Samfund nr. 44.

Hjarvard, S. (2002). Seernes Reality. In MedieKultur nr. 34.

Horton, D. \& R. Wohl, R. (1997/1956). Massekommunikation og parasocial interaktion: Et indlæg om intimitet på afstand. In MedieKultur nr. 26.

Huizinga, J. (1958). Homo Ludens: Om kulturens oprindelse i leg. København: Gyldendal.

Höijer, B. (1991). Lustfylld glömska, kreativ illusion och realitetsprörning. Publik- och programforskningsavdelingen nr. 15: Sveriges Radio.

Höijer, B. (1996). Audiences' expectations on the interpretations of different television genres: A socio-cognitive approach. IAMCR, Sydney.

Höijer, B. \& Werner, A. (1998). Cultural Cognition. New perspctives in audience theory. Göteborg: Nordicom.

Højbjerg, L. (1989). Reception af levende billeder. København: Akademisk Forlag.

Jørholt, E. (red.) (1995). Ind i filmen. København: Medusa.

Knudsen, E. (red.) (1998). Programkwalitet. Kultur, Sport, Underholdning. Danmarks Radio.

Kvale, S. (1994). Interview: Introduktion til det kvalitative forskningsinterview. København: Hans Reitzels Forlag.

Larsen, P.H. (1990). Faktion som udtryksmiddel. Viborg: Forlaget Amanda.

Larsen-Ledet, J.P. (2001). På linje med seerne. Upubliceret specialeafhandling, RUC.

Lindlof, T.R. (1995). Qualitative Communication Research Methods. London: Sage.

Loy, Jr. J.W. (1981). The Nature of Sport: a Definitional Effort. In G.S. Kenyon, B. McPherson \& J.W. Loy Jr., Sport, Culture and Society: A reader on the Sociology of Sport. Philadelphia: Lea \& Febiger.

Meyrowitz, J. (1986). No Sense of Place, The Impact of Electronic Media on Social Behavior. New York: Oxford University Press.
Miles, M.B. \& Hubermann, A. M. (1994). Qualititative Data Analysis. London: Sage.

Olsen, H. (2002). Kvalitative Kvaler. København: Akademisk Forlag.

Rothenbuhler, E.W. (1998). Ritual communication. From everyday Conversation to Mediated Ceremony. Thousand Oaks: Sage.

Schrøder, K. (2003). Generelle aspekter ved mediereception - et bud på en multidimensional model for analyse af kvalitative receptionsinterviews. In MedieKultur nr. 35.

Seale, C. (1999). The Quality of Qualitative Research. London: Sage.

Sørensen, K.I. (1989). Psykosemiologisk receptionsteori. In L. Højbjerg (red.), Reception af levende billeder. København: Akademisk Forlag

Wilson, T. (1993). Watching Television. Hermeneutics, Reception and Popular Culture. Cambridge: Polity Press.

\section{Noter}

1 Det var den franske semiolog Christian Metz, der i essayet "Le signifiant imaginaire" i 1975 overførte Jacques Lacans spejlteori til filmteorien. En anden bidragyder i denne tradition er tyskeren Günther Salje, hvis teori, har været rettet mod både film- og tv, idet han har fokuseret på de audiovisuelle mediers fælles træk som præsentative symbol-former.

2 Det er disse karakteristika, som har ledt Günther Salje til at karakterisere film- og tv-mediets udtryk som præsentative symbolformer med udgangspunkt i Susanne K. Langers begreb.

3 Et dansk eksempel på spilteori er Nils Gunder Hansens og Frederik Stjernfeldts fænomenologiske og sprogfilosofisk inspirerede analyse af fodbold som konstitutivt spilfænomen, der er det konkrete udgangspunkt for denne artikel. Beslægtede synsvinkler på sport som spil kan findes i John W. Loy Jr.'s strukturelle analyse af sportsspillets kompetitive element (Loy, 1981). Og i et bredere perspektiv byder også Johan Huizingas (1958) kulturelle analyse af legens væsen og Roger Callois (2001) efterfølgende kritik af Huizinga og mere udfoldede beskrivelse af forskellige former for spil på et frugtbart perspektiv på spil-fænomener.

4 Flere publikumsundersøgelser har dokumenteret at mange mandlige fodboldfans ikke interesserer sig for deres idolers privatliv og evne til f.eks. at udfylde rollen som far eller ægtemand. Det er udelukkende vedkommendes kvaliteter på fodboldbanen, som har deres interesse. Se f.eks. Larsen Ledet (2001).

Kirsten Frandsen er lektor ved Institut for Informations- og medievidenskab, Aarhus Universitet.

Hanne Bruun er lektor ved Institut for Informations- og medievidenskab, Aarhus Universitet. 